\title{
Kurdish Language
}

National Cancer Institute

\section{Source}

National Cancer Institute. Kurdish Language. NCI Thesaurus. Code C153992.

A continuum of Northwestern Iranian languages spoken by the Kurdish people in Western Asia. 